\title{
ON A COLLECTION OF CARIDEAN SHRIMPS (DECAPODA, CARIDEA) FROM ST. HELENA, SOUTH-CENTRAL ATLANTIC, WITH FURTHER RECORDS FROM ASCENSION ISLAND
}

\author{
BY
}

\author{
SAMMY DE GRAVE ${ }^{1,5}$ ), JUDITH BROWN ${ }^{2}$ ), PETER WIRTZ ${ }^{3}$ ) and ARTHUR ANKER ${ }^{4}$ ) \\ 1) Oxford University Museum of Natural History, Parks Road, Oxford, U.K. \\ 2 ) University of Stirling, Stirling, FK9 4LA, Scotland, U.K. \\ 3 ) Centro de Ciências do Mar, Universidade do Algarve, P-8005-139 Faro, Portugal \\ 4 ) Universidade Federal de Goiás, Campus Samambaia, Instituto de Ciências Biológicas — ICB-5, \\ Av. Esperança, s/n, 74690-900 Goiânia, Goiás, Brazil
}

\begin{abstract}
We report on a recent collection of caridean shrimps from St. Helena in the south-central Atlantic Ocean, raising the total number of species known from the island to 24. Six species are newly recorded for the area, with no endemic species present. Additional three species are recorded from Ascension Island. A close biogeographical connection between the caridean faunas of St. Helena and Ascension Island is evident.
\end{abstract}

\section{RÉSUMÉ}

Le présent article présente un rapport sur une collecte récente de crevettes Carides réalisée autour de l'île de Sainte-Hélène dans l'Océan Atlantique central, augmentant le nombre total des espèces connues de cette île à 24 . Six espèces sont signalées de cette zone pour la première fois, aucune espèce n'étant cependant endémique de l'île de Sainte-Hélène. Trois espèces sont également signalées pour la première fois de l'île de l'Ascension. Une étroite connexion biogéographique entre les faunes Carides des îles Sainte-Hélène et Ascension est évidente.

\section{INTRODUCTION}

St. Helena is one of the world's most isolated islands, situated in the central part of the South Atlantic Ocean, with the nearest landmass being Ascension Island, about $1300 \mathrm{~km}$ to the north, and almost $2000 \mathrm{~km}$ off the coast of western Africa (Namibia/Angola) and over $4000 \mathrm{~km}$ from the coast of South America (Brazil).

5) Corresponding author; e-mail: sammy.degrave@oum.ox.ac.uk

(C) Koninklijke Brill NV, Leiden, 2019 
Although the island has long fascinated biologists, the marine fauna remains fragmentarily known, especially for invertebrates.

The last (and first) synoptic study on decapod crustaceans was by Chace (1966) who drew together the earlier scattered records and listed 23 species of Decapoda, amongst which only five species of caridean shrimps. However, Chace had overlooked the record of Trachycaris rugosa Spence Bate, 1888 in Gurney (1940), bringing the total to six species. Since then, there have been very few additional reports on the shrimp fauna of this island. Both Christoffersen (1979) and Fransen (2002) listed several specimens examined from St. Helena, but based on material already reported in Chace (1966). Fransen (1989) mentioned a record of Thor amboinensis (De Man, 1888) from St. Helena, in association with the sea anemone Telmatactis sp., made by J. C. den Hartog in 1983, however, without specimens collected. De Grave (2007) recorded Gnathophylleptum tellei d'Udekem d'Acoz, 2001 from the island, based on a single specimen collected in 1977. In summary, prior to 2010, the known caridean shrimp fauna of St. Helena stood at a paltry eight species.

In more recent years (2012-2014), a widespread baseline survey was undertaken by the Environmental Management Department of the St. Helena Government, led by one of the authors (JB). This was supplemented by material originating from a targeted collecting trip by one of the authors (PW) in 2014. Photographic records of selected species (identified by SDG) were published in Brown (2014), adding a further six species to the known fauna. Based on the 2012-2014 collections, two new species have already been described from St. Helena, viz., Lysmata napoleoni De Grave \& Anker, 2018 (also known to occur at Ascension Island) and Hippolyte karenae Fransen \& De Grave, 2019 (De Grave \& Anker, 2018; Fransen \& De Grave, 2019). This brings the total number of caridean shrimps known from St. Helena to date up to 16 species. The present contribution reports on the remainder of this collection, documenting the photo vouchers in Brown (2014), as well as providing further records. In addition, three species are newly reported for Ascension Island, based on a collecting trip in July 2015 by one of the authors (PW).

All material is deposited in the collections of the Oxford University Museum of Natural History (OUMNH.ZC); the following abbreviations are used throughout the text: pocl (post-orbital carapace length, in $\mathrm{mm}$ ), cl (carapace length, including rostrum, in $\mathrm{mm}$ ) and fen (field collection number). To avoid repetition, geographical coordinates of collecting sites in St. Helena are listed in table I, where known. 
TABLE I

Geographical coordinates (in decimal degrees) of sampling locations in St. Helena

\begin{tabular}{lcc}
\hline Location & Latitude & Longitude \\
\hline Banks & -15.912 & -5.709 \\
Bedgellet & -15.946 & -5.755 \\
Billy May Revenge & -15.947 & -5.756 \\
Buoy's Hole & -15.911 & -5.688 \\
Buttermilk Point & -15.907 & -5.707 \\
Egg Island & -15.971 & -5.771 \\
Flat Rock & -15.990 & -5.664 \\
Frontier & -15.937 & -5.744 \\
James Bay wharf steps & -15.921 & -5.718 \\
Ladder Hill & -15.926 & -5.726 \\
Lighter Rock & -15.955 & -5.762 \\
Long Ledge & -15.945 & -5.762 \\
Lower Lady's Chair & -15.966 & -5.766 \\
Merriment Island & -15.912 & -5.669 \\
Munden's Point & -15.921 & -5.718 \\
Papa Nui wreck & -15.922 & -5.720 \\
Red Island & -15.940 & -5.742 \\
Scraggy Point & -15.928 & -5.650 \\
Smooth Rock & -15.989 & -5.785 \\
Speery Island & -16.029 & -5.753 \\
\hline
\end{tabular}

TAXONOMY

Order DECAPODA Latreille, 1802

Infraorder CARIDEA Dana, 1852

Family ALPHEIDAE Rafinesque, 1815

Alpheopsis aequalis Coutière, 1897 (s. lat.)

Material examined.- Ascension Island: 1 male (cl 2.4), Bates Point, 16.vii.2015, OUMNH.ZC. 2018-01-20.

Remarks. - Alpheopsis aequalis is currently considered an almost pantropical species complex, with at least two morphologically distinct taxa occurring in the western Atlantic (Anker et al., 2016). The single male specimen from Ascension Island represents the first record of this taxon from the central Atlantic. However, its exact identity must await a full resolution of the complex worldwide.

\section{Alpheus cedrici Anker \& De Grave, 2012}

Previous record from St. Helena.- Brown, 2014: 59 (colour photograph).

Material examined.- St. Helena: 2 females (cl 5.0), Munden's Point, 10.3 m, 23.ii.2013, fcn 130223/17/02, OUMNH.ZC.2018-04-12; 1 ov. female (cl 11.8), Smooth Rock west side, 20.9 m, 19.iv.2013, fen 130426/Q37/02, OUMNH.ZC.2018-04-13; 1 spec. (cl 9.0), Lighter Rock, 17.7 m, 
8.v.2013, fcn 130508/Q53/02, OUMNH.ZC.2018-04-14; 1 ov. female (cl 11.3), Long Ledge, 15 m, 15.i.2014, fcn 140115/61/04, OUMNH.ZC.2018-04-15; 1 male (cl 11.5), Billy May's Revenge, 15 m, 18.i.2014, fen 140118/66/02, OUMNH.ZC.2018-04-16; 1 male (cl 11.8), Buoy's Hole, 17.7 m, 19.i.2014, fen 140119/67/01-02, OUMNH.ZC.2018-04-17.

Remarks.- This recently described, conspicuous species of snapping shrimp remains only known from Ascension Island (type locality, see Anker \& De Grave, 2012) and from St. Helena based on the above-listed material and the photographic record in Brown (2014).

\section{Alpheus crockeri (Armstrong, 1941)}

Material examined.- St. Helena: 1 ov. female (cl 7.0), Lighter Rock, 17.7 m, 8.v.2013, fcn 130508/Q53/01, OUMNH.ZC.2018-04-18; 1 ov. female (cl 11.6), Bedgellet, 18 m, 12.i.2014, fcn 140112/57/01, OUMNH.ZC.2018-04-19.

Remarks. - As with the Ascension Island material reported in De Grave et al. (2017), the material from St. Helena conforms to the description of the eastern Atlantic material by Crosnier \& Forest (1966). Doubt remains, however, as to whether all the Atlantic populations reported under this name or under the name $A$. hortensis Wicksten \& McClure, 2003, are indeed the same taxon as the widespread Indo-West Pacific A. crockeri (see also Anker et al., 2016) The present specimens constitute a new record for St. Helena.

\section{Alpheus dentipes Guérin, 1832}

Material examined.- St. Helena: 1 male (cl 4.2), Billy May's Revenge, 14.4 m, 9.v.2013, fcn 130509/Q55/01, OUMNH.ZC.2018-04-20.

Remarks.- This species is currently seen as widespread in the eastern Atlantic, from western Europe southwards to Cameroon and the central Atlantic, including Ascension Island (Manning \& Chace, 1990) and now St. Helena. However, as the type locality of $A$. dentipes is in the Mediterranean, the taxonomic status of the central and tropical eastern Atlantic populations is currently being investigated by molecular analyses.

\section{Alpheus paracrinitus Miers, 1881 (s. lat.)}

Previous record from St. Helena.- Brown, 2014: 59 (colour photograph).

Material examined.- St. Helena: 1 male (cl 4.5), Papa Nui wreck, 12.4 m, 14.i.2013, fcn 130114/05/05, OUMNH.ZC.2018-04-21; 1 ov. female (cl 6.0), Merriment Island, 10.2 m, 19.iv.2013, fcn 130419/Q29/3, OUMNH.ZC.2018-04-22.

Remarks.-Alpheus paracrinitus forms a large pantropical species complex (Anker et al., 2016). The exact identity of the present material is thus unknown. 
Metalpheus paragracilis (Coutière, 1897)

Previous record from St. Helena.—Chace, 1966: 627 (as Alpheus paragracilis).

Material examined.- St. Helena: 1 male (cl 4.0), 1 ov. female (cl 4.5), James Bay Wharf steps, 8.5 m, 15.viii.2013, fen 130815/39/01, OUMNH.ZC.2018-04-23; 1 male (cl 4.8), same locality, 11.3 m, 17.i.2014, fen 140117/65/02, OUMNH.ZC.2018-04-24.

Remarks. - This is a widespread Indo-West Pacific species (or species complex), which is also known from the central Atlantic (Ascension Island, St. Helena) and a questionable record from Florida (Anker et al., 2016).

\section{Synalpheus fritzmuelleri Coutière, 1909}

Previous records from St. Helena.-Chace, 1966: 629; Christoffersen, 1979: 342.

Material examined.- St. Helena: 1 female (cl 5.0), Papa Nui wreck, 12.4 m, 14.i.2013, fcn 130123130123/05/06, OUMNH.ZC.2018-04-25; 1 ov. female (cl 6.5), 1 female (cl 4.2), Frontier, 26.2 m, 17.i.2013, fcn 130117/06/09, OUMNH.ZC.2018-04-26; 1 ov. female (cl 6.0), Buttermilk Point, $22.1 \mathrm{~m}$, 26.i.2013, fcn 130126/09/02, OUMNH.ZC.2018-04-27; 1 ov. female (cl 6.8), Munden's Point, 9.8 m, 19.iii.2013, fcn 130319/21/01, OUMNH.ZC.2018-04-28; 1 female (cl 6.0), Flat Rock, 16.4 m, 23.iv.2013, fcn 130423/Q31/02, OUMNH.ZC.2018-04-29; 1 female (cl 5.5), James Bay Wharf steps, 9.7 m, 28.iii.2013, fcn 130328/Q4/04, OUMNH.ZC.2018-04-30; 1 female (cl 5.5), Smooth Rock west side, 20.9 m, 26.iv.2013, fen 130426/Q37/01, OUMNH.ZC.2018-04-31; 1 female (cl 6.0), Lower Lady's Chair, 19.6 m, 7.v.2013, fen 130507/Q47/01, OUMNH.ZC.2018-0432; 1 ov. female (cl 4.5), Papa Nui wreck, 10.9 m, 16.vii.2013, fen 130716/28/08, OUMNH.ZC. 2018-04-33; 1 female (cl 5.2), Buoy's Hole, 17.7 m, 19.i.2014, fcn 140119/67/01-02-05, OUMNH. ZC.2018-04-34.

Remarks.- A widespread and commonly recorded, western-central Atlantic species of Synalpheus.

\section{Family BARBOURIIDAE Christoffersen, 1987}

Janicea antiguensis (Chace, 1972)

Previous record from St. Helena.- Brown, 2014: 60 (colour photograph).

Material examined.- St. Helena: 1 male (pocl 5.2), Papa Nui wreck, 12.5 m, 21.i.2014, fcn 140121/70/02, OUMNH.ZC.2018-04-35.

Remarks. - This amphi-Atlantic species is known in the eastern Atlantic, more precisely from Cape Verde, São Tomé, and the Canary Islands (Wirtz, 2004), as well as from St. Helena by the photographic record in Brown (2014), confirmed by the present material.

Family HiPPOLYTIDAE Spence Bate, 1888

Trachycaris restricta (A. Milne-Edwards, 1878)

Previous records from St. Helena.- Gurney, 1940: 121; Brown, 2014: 61 (colour photograph).

Material examined.- St. Helena: 1 ov. female (pocl 3.6), Banks, 16.2 m, 17.i.2013, fcn 131017/Q125/1, OUMNH.ZC.2018-04-36; 1 female (pocl 1.8), locality and depth unknown, 21.x. 
2013, fen 131021/49/01, OUMNH.ZC.2018-04-37; 1 ov. female (pocl 4.6), Munden's Point, 10.3 m, 23.ii.2013, fen 130223/17, OUMNH.ZC.2018-04-38;1 ov. female (pocl 4.0), Buttermilk Point, 18.9 m, 25.i.2014, fen 140125/77/02, OUMNH.ZC.2018-04-39. Ascension Island: 1 female (pocl 2.4), Pyramid dive site, 14.vii.2015, OUMNH.ZC.2018-01-23.

Remarks. - The taxonomy of the Atlantic species of Trachycaris remains somewhat confusing. Criales (1992) suggested that two species are present, $T$. restricta in the eastern Atlantic and T. rugosa Spence Bate, 1888 in the western Atlantic, although a specimen from Bermuda was assigned to T. restricta. Although the species was already known from St. Helena, it is here newly recorded for Ascension Island. The identity of the material recorded under T. restricta from the eastern Pacific (Wicksten \& Hendrickx, 2003) remains to be confirmed.

\section{Family LYSMATIDAE Dana, 1852}

Lysmata grabhami (Gordon, 1935)

Previous record from St. Helena.—-Brown, 2014: 56 (colour photograph).

Material examined.- St. Helena: 1 hermaphrodite (pocl 13.5), Scraggy Point, 13.6 m, 19.v.2013, fen 130519/Q83/01, OUMNH.ZC.2018-04-40; 1 hermaphrodite (pocl 6.2), Stringers, near Thompson's Valley Island, 21 m, 30.i.2014, fcn 140130/85/01, OUMNH.ZC.2018-04-41.

Remarks.- A widespread amphi-Atlantic species, previously recorded from St. Helena by a colour photograph published by Brown (2014); this photographic record is confirmed by the present material.

\section{Lysmata moorei (Rathbun, 1901)}

Previous record from St. Helena.-Brown, 2014: 57 (colour photograph, as Lysmata sp.).

Material examined.- St. Helena: 3 ov. hermaphrodites (pocl 8.0-8.7), 4 hermaphrodites (pocl 4.8-6.5), Sandy Bay, tide pools, 17.i.2014, fen 140117/69, OUMNH.ZC.2018-04-42.

Remarks.- Currently seen as a single widespread amphi-Atlantic species, although could also be a species complex. Previously known from St. Helena on the basis of a photographic record in Brown (2014), which is herewith confirmed.

\section{Family Palaemonidae Rafinesque, 1815}

Balssia gasti (Balss, 1921)

Material examined.- St. Helena: 5 spec. (pocl 0.8-1.6), Speery Island, 20.4 m, 16.i.2014, fen 140116/63/02, OUMNH.ZC.2018-04-43; 2 females (pocl 1.1-1.3), same collection data, fcn 140116/63/05, OUMNH.ZC.2018-04-44; 23 spec. (pocl 1.2-1.9), same collection data, fen 140114/ 60/3-6-7, OUMNH.ZC.2018-04-45; 1 male (pocl 1.5), Long Ledge, 15 m, 21.i.2014, fcn 140121/ 73/01, OUMNH.ZC.2018-04-46.

Remarks.- An associate of various anthozoans, known from the Mediterranean southwards to São Tomé (Wirtz \& d'Udekem d'Acoz, 2008). Now recorded from 
St. Helena, which is also the first record of the species for the central Atlantic. The Speery Island specimens were collected from the hydroid Macrorhynchia filamentosa (Lamarck, 1816), whilst the Long Ledge specimen was collected from an unidentified gorgonian.

\section{Brachycarpus biunguiculatus (Lucas, 1846)}

Previous records from St. Helena.—Chace, 1966: 625; Brown, 2014: 58 (colour photograph).

Material examined.- St. Helena: 1 male (pocl 4.0), Munden's Point, 10.9 m, 23.i.2013, fcn 130123/08/06, OUMNH.ZC.2018-04-47; 1 female (pocl 3.5), same locality and depth, 15.ii.2013, fcn 130215/14/04, OUMNH.ZC.2018-04-48; 1 female (pocl 7.5), same locality, $10.3 \mathrm{~m}$, 23.ii.2013, fcn 130223/17/06, OUMNH.ZC.2018-04-49; 1 male (pocl 4.8), 1 female (pocl 3.6), same collection data, fcn 130223/17/05, OUMNH.ZC.2018-04-50; 1 male (pocl 5.0), Buttermilk Point, 22.3 m, 16.v.2013, fcn 130516/Q77/02, OUMNH.ZC.2018-04-51; 1 female (pocl 4.6), Speery Island, 20.4 m, 16.i.2014, fen 140116/63/02-03, OUMNH.ZC.2018-04-52.

Remarks. - A widespread, common, pantropical-temperate species. Previously recorded from St. Helena based on a colour photograph in Brown (2014).

\section{Gnathophylleptum tellei d'Udekem d'Acoz, 2001}

Previous records from St. Helena.—-De Grave, 2007: 893; Brown, 2014: 57 (colour photograph).

Material examined.- St. Helena: 1 female (pocl 2.8), Banks, 9.1 m, 17.x.2013, fcn 131017/ Q124/01, OUMNH.ZC.2018-04-53.

Remarks. - This spectacular but rarely recorded species is currently known only from the Canary Islands (type locality) and St. Helena (De Grave, 2007; Brown, 2014; present study), but is likely more widespread in the eastern-central Atlantic.

\section{Gnathophyllum americanum Guérin-Méneville, 1855}

\section{Previous record from St. Helena._- Brown, 2014: 57 (colour photograph).}

Material examined.- St. Helena: 1 female (pocl 3.6), Munden's Point, 10.3 m, 23.ii.2013, fcn 130223/17/04, OUMNH.ZC.2018-04-54; 1 female (pocl 2.8), same locality, 9.8 m, 19.iii.2013, fcn 130319/21/02, OUMNH.ZC.2018-04-55; 1 female (pocl 2.6), Joan's Point, 18.4 m, 20.v.2013, fcn 130520/Q85/01, OUMNH.ZC.2018-04-56.

Remarks. - Currently seen as a widespread pantropical species, although the status of the Indo-West Pacific populations and several synonyms remains questionable. Previously noted from St. Helena on the basis of a photographic record in Brown (2014), which is confirmed by the present material. 
Palaemonella atlantica Holthuis, 1951

Material examined.- St. Helena: 1 male (pocl 2.7), 1 ov. female (pocl 2.2), Ladder Hill yacht mooring, 19.5 m, 24.i.2013, fcn 131224/55/04, OUMNH.ZC.2018-04-57; 1 male (pocl 2.8), Long Ledge, 20 m, 15.i.2014, fcn 140115/61/08, OUMNH.ZC.2018-04-58.

Remarks.- Widespread, but rarely recorded species, known from Madeira southwards to Cape Verde, and recorded from St. Helena and the central Atlantic for the first time. The specimen from Long Ledge was found on the black coral Plumapathes pennacea (Pallas, 1766) (Antipatharia).

\section{Pontonia pinnophylax (Otto, 1821)}

Previous records from St. Helena.- Chace, 1966: 626; Fransen, 2002: 176; Brown, 2014: 61 (colour photograph).

Material examined.- St. Helena: 1 male (pocl 8.5), 1 female (pocl 10.5), Merriment Island, 16.3 m, 19.iv.2013, fen 130419/Q30/2, OUMNH.ZC.2018-04-59.

Remarks.- A widespread and frequently recorded eastern and central Atlantic species. The present specimens, a mated pair, were obtained from the mantle cavity of the pen shell, Pinna rudis Linnaeus, 1758.

\section{Rapipontonia platalea (Holthuis, 1951)}

Material examined.- St. Helena: 1 male (pocl 2.0), 1 female (pocl 2.2), Long Ledge, $15 \mathrm{~m}$, 14.i.2014, fen 140114/60/3-6-7, OUMNH.ZC.2018-04-60; 1 female (pocl 2.1), Speery Island, 20.4 m, 16.i.2014, fcn 140116/63/05, OUMNH.ZC.2018-04-61. Ascension Island: 4 spms., Rocket Pad dive site, 17.vii.2015, OUMNH.ZC2018-01-17; 9 spms., same location, 18.vii.2015, OUMNH. ZC.2018-01-19.

Remarks.- Widespread, but infrequently recorded, amphi-Atlantic species, recorded from St. Helena and Ascension Island for the first time. All St. Helena specimens were collected from the black coral Plumapathes pennacea.

Family PROCESSIDAE Ortmann, 1896

Processa packeri Manning \& Chace, 1990

Material examined.- St. Helena: 1 spm. (damaged, sex not determined) (pocl 2.6), Egg Island, 14 m, 1.viii.2013, fcn 130801/32/06, OUMNH.ZC.2018-04-62.

Remarks. - Although the specimen is damaged, it fits the diagnosis of the species in Manning \& Chace (1990). The species was formerly considered to be endemic to Ascension Island, but is now recorded also from St. Helena. 


\section{Family RHYNCHOCINETIDAE Ortmann, 1890}

Cinetorhynchus rigens (Gordon, 1936)

Previous record from St. Helena.- Brown, 2014: 58 (colour photograph).

Material examined.- St. Helena: 1 male (pocl 11.0), Papa Nui wreck, 12.5 m, 5.ii.2013, fcn 130205/12/02, OUMNH.ZC.2018-04-07; 1 male (pocl 7.8), Egg Island, 14 m, 1.viii.2013, fcn 130801/32/04, OUMNH.ZC.2018-04-08; 1 female (pocl 4.0), James Bay Wharf steps, $10.2 \mathrm{~m}$, 26.i.2014, fen 140126/78/02-05, OUMNH.ZC.2018-04-06.

Remarks. - A relatively widespread amphi-Atlantic species. Previously noted from St. Helena on the basis of a photographic record in Brown (2014), which is confirmed by the present material.

\section{Family THORIDAE Kingsley, 1879}

\section{Thor sp.}

Previous records from St. Helena.- Brown, 2014: 60 (colour photograph, as T. cf. manningi); (?) Fransen, 1989: 133 (as T. amboinensis).

Material examined.-St. Helena: 1 male (pocl 1.4), Billy May's Revenge, 10 m, 26.viii.2013, fcn 130826/41/01, OUMNH.ZC.2018-04-63; 1 ov. female (pocl 1.9), Red Island, $16.3 \mathrm{~m}, 22 . i .2014$, fcn 140122/72/04, OUMNH.ZC.2018-04-64; 7 spms. (pocl 1.0-2.2), James Bay Wharf steps, $10.2 \mathrm{~m}$, 26.i.2014, fen 140126/78/02-05, OUMNH.ZC.2018-04-65; 1 ov. female (pocl 2.8), Egg Island, 24.2 m, 27.i.2014, fen 140127/79/02, OUMNH.ZC.2018-04-66; 1 juvenile (pocl 0.8), Long Ledge, 15 m, 14.iv.2014, fen 140414/60/3-6-7, OUMNH.ZC.2018-04-67.

Remarks. - The exact species status of these specimens is unclear. Morphologically, they are extremely close to T. amboinensis (De Man, 1888), with no discernible morphological differences, but with a different colour pattern (see Brown, 2014, as T. cf. manningi). These specimens will form the subject of a further study.

\section{DISCUSSION}

The present study raises the total number of caridean shrimps known from St. Helena to 24 species. Of the species recorded by Chace (1966), only one species, Alpheus macrocheles (Hailstone, 1835), was not present in the 2012-2014 collection.

The relatively low and probably still incomplete number of species currently known from St. Helena makes biogeographical comparisons with other Atlantic areas premature. Nevertheless it is evident from the species composition that St. Helena has a close faunal affinity with Ascension Island, as already noted by Manning \& Chace (1995). The currently known shallow-water caridean fauna of Ascension Island recorded in literature stands at 28 species (Brown et al., 2016; De Grave et al., 2017; De Grave \& Anker, 2018), with an additional three species recorded herein, bringing the current total to 31 species. 
At present, only one species, the recently described $H$. karenae, could currently be considered as endemic to St. Helena, although it seems likely, given the close zoogeographical connection between these two central Atlantic islands, that most if not all taxa currently only known from Ascension Island will in the future also be found at St. Helena and vice versa.

\section{ACKNOWLEDGEMENTS}

PW wishes to thank the Centre for Marine Sciences (CCMAR) of the University of Algarve for partially funding the trips to Ascension Island and St. Helena, through the Portuguese Foundation for Science and Technology project UID/Multi/04326/2013.

\section{REFERENCES}

Anker, A. \& S. De Grave, 2012. Description of Alpheus cedrici sp. n., a strikingly coloured snapping shrimp (Crustacea, Decapoda, Alpheidae) from Ascension Island, central Atlantic Ocean. ZooKeys, 183: 1-15.

Anker, A., M. TAVAres \& J. B. MendonçA, 2016. Alpheid shrimps (Decapoda: Caridea) of the Trindade \& Martin Vaz Archipelago, off Brazil, with new records, description of a new species of Synalpheus and remarks on zoogeographical patterns in the oceanic islands of the tropical southern Atlantic. Zootaxa, 4138: 1-58.

Brown, J., 2014. Marine life of St. Helena: 1-220. (Pisces Publications, Newbury).

Brown, J., K. Downes, R. J. Mrowicki, E. L. Nolan, A. J. Richardson, F. Swinnen \& P. WIRTZ, 2016. New records of marine invertebrates from Ascension Island (central Atlantic). Arquipélago, 33: 71-79.

Chace, F. A., JR., 1966. Decapod crustaceans from St. Helena Island, South Atlantic. Proceedings of the United States National Museum, 118: 623-661.

Christoffersen, M. L., 1979. Campagne de la Calypso au large des côtes Atlantiques de l'Amérique du Sud (1961-1962). I. Decapod Crustacea: Alpheoida. Annales de l'Institut Océanographique, 55(Suppl.): 297-377.

CRIAles, M. M., 1992. Redescription of the hippolytid shrimp Trachycaris rugosa (Bate) (Crustacea: Decapoda: Caridea) from the western Atlantic, with notes on sexual dimorphism. Proceedings of the Biological Society of Washington, 105: 562-570.

Crosnier, A. \& J. Forest, 1966. Crustacés Décapodes: Alpheidae. Campagne de la Calypso dans le Golfe de Guinée et aux Iles Principe, São Tome et Annobon (1956), et Campagne aux Iles du Cap Vert (1959) (suite), XXVII: Résultats scientifiques des campagnes de la "Calypso", Fascicule 7. Annales de l'Institut Océanographique, 44: 199-314.

DE GRAVE, S., 2007. On the occurrence of Gnathophylleptum tellei d'Udekem d'Acoz, 2001 (Decapoda, Gnathophyllidae) in St. Helena, South Atlantic Ocean. Crustaceana, 80: 893-895.

De Grave, S. \& A. ANKer, 2018. A new, distinctly coloured species of Lysmata Risso, 1816 (Malacostraca: Decapoda: Lysmatidae) from the south-central Atlantic. Zootaxa, 4429: 390400.

De Grave, S., A. Anker, P. C. Dworschak, P. F. Clark \& P. Wirtz, 2017. An updated checklist of the marine Decapoda of Ascension Island, central Atlantic Ocean. Journal of the Marine Biological Association of the United Kingdom, 97: 759-770. [Available online as FirstView in 2014.] 
FRANSEN, C. H. J. M., 1989. Notes on caridean shrimps collected during the Snellius-II expedition. I. Associates of Anthozoa. Netherlands Journal of Sea Research, 23: 131-147.

FRANSEN, C. H. J. M., 2002. Taxonomy, phylogeny, historical biogeography, and historical ecology of the genus Pontonia Latreille (Crustacea: Decapoda: Caridea: Palaemonidae). Zoologische Verhandelingen, 336: 1-433.

Fransen, C. H. J. M. \& S. De Grave, 2019. Two new species of Hippolyte from the Tropical Central and East Atlantic (Crustacea, Decapoda, Caridea). Zootaxa, 4550: 201-220.

Gurney, R., 1940. The larvae of the decapod genus Trachycaris Calman. Proceedings of the Zoological Society of London, (B) 110: 121-125, pls. 1-3.

Manning, R. B. \& F. A. CHACE, JR., 1990. Decapod and stomatopod Crustacea from Ascension Island, South Atlantic Ocean. Smithsonian Contributions to Zoology, 503: 1-91.

WiCKSTEN, M. K. \& M. E. HENDRICKX, 2003. An updated checklist of benthic marine and brackish water shrimps (Decapoda: Penaeoidea, Stenopodidea, Caridea) from the Eastern Tropical Pacific. Contributions to the Study of East Pacific Crustaceans, 2: 49-76.

WIRTZ, P., 2004. Four amphi-Atlantic shrimps new for São Tomé and Príncipe (eastern central Atlantic). Arquipélago - Life and Marine Sciences, 21(A): 83-85.

WirtZ, P. \& C. D'UdEKEM D'ACOZ, 2008. Crustaceans associated with Cnidaria, Bivalvia, Echinoidea and Pisces at São Tomé and Príncipe islands. Arquipélago - Life and Marine Sciences, 25: 63-69.

First received 3 April 2019.

Final version accepted 12 April 2019. 